\title{
Enzymatic Release and Macrolactonization of Cryptophycins from a Safety-Catch Solid Support**
}

\author{
Wolfgang Seufert, Zachary Q. Beck, and David H. Sherman*
}

Many natural products of pharmacological importance consist of macrocyclic structures, for example the polyketide antibiotic erythromycin, the non-ribosomal peptide cyclosporine, and the cryptophycins, a family of depsipeptides and potent antitumor agents. In nature, these macrocyclic compounds are synthesized by modular enzymatic "assembly lines" consisting of polyketide (PK) synthases, non-ribosomal peptide (NRP) synthetases, and hybrid NRP/PK synthetases. ${ }^{[1]}$ During biosynthesis the intermediates are bound to the enzymes by a thioester, and in the final step cyclized by an integrated C-terminal thioesterase (TE) domain. The analogy of NRP and PK biosynthesis to solid-phase synthetic methodology inspired us to develop a solid-phase chemoenzymatic synthetic approach for cryptophycins and potential analogues.

Previous successful strategies for the synthesis and enzyme-catalyzed on-resin cyclization of peptides involved substrates bound by means of an ester or thioester linkage to a solid support. ${ }^{[2]}$ In addition, recent reports of solid-phase synthesis of linear polyketides under diverse reaction conditions encouraged us to design a chemoenzymatic on-resin macrocyclization strategy using a robust linker that is stable to most chemical synthesis conditions. ${ }^{[3]}$ To facilitate the synthesis of large libraries of macrocyclic compounds we also required a method suitable for the direct release and cyclization of compounds on-resin. This model study describes the solid-phase synthesis and on-resin cyclization of three cryptophycin analogues.

Cryptophycins, a class of macrocyclic depsipeptides, were first isolated in the 1990s from Nostoc sp. ATCC53789 and Nostoc sp. GSV 224..$^{[4]}$ The therapeutic potential of these natural products arises from their potent and highly selective cytotoxicity even for multi-drug-resistant tumor cell lines. The biological properties have generated significant interest in their large-scale isolation, total synthesis, and modification. ${ }^{[5]}$ Currently, more than 25 naturally occurring cryptophycins and several hundred synthetic analogues have been described. Several of these analogues have been identified as advanced

[*] Dr. W. Seufert, ${ }^{[+]}$Dr. Z. Q. Beck, ${ }^{[+]}$Prof. Dr. D. H. Sherman Life Sciences Institute

Departments of Medicinal Chemistry, Chemistry, Microbiology and Immunology

The University of Michigan

Ann Arbor, MI 48109 (USA)

Fax: $(+1)$ 734-615-3641

E-mail: davidhs@umich.edu

$\left.{ }^{+}\right]$These authors contributed equally to this work.

[**] This project was generously funded by the Swiss National Science Foundation (PBBS2-113008 to W.S.) and NIH CA076477 (to D.H.S.)

Dupporting information for this article is available on the WWW under http://www.angewandte.org or from the author. anticancer therapeutic leads that are being considered for clinical evaluation. ${ }^{[6]}$ Most natural cryptophycins consist of four hydroxy or amino acids (units A-D, respectively): $\delta$ hydroxy phenyloctenoic acid, 3-chloro- $O$-methyl-D-tyrosine, $(R)$ - $\alpha$-methyl- $\beta$-alanine (or $\beta$-alanine), and L-leucic acid (Figure 1). ${ }^{[7]}$

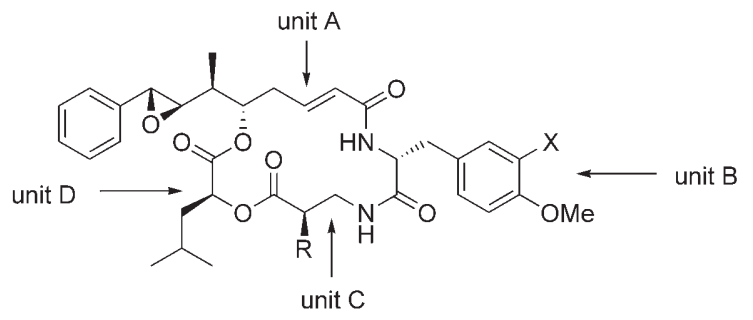

$\mathrm{R}=\mathrm{Me}, \mathrm{X}=\mathrm{Cl}$, cryptophycin-1

$\mathrm{R}=\mathrm{H}, \mathrm{X}=\mathrm{Cl}$, cryptophycin-2

$\mathrm{R}=\mathrm{H}, \mathrm{X}=\mathrm{H}$, cryptophycin-24 (arenastatin)

Figure 1. Structural formulae of cryptophycin-1, cryptophycin-21, and cryptophycin-24 (arenastatin).

Recently, the gene cluster responsible for production of cryptophycins was characterized from the cyanobacteria Nostoc sp. ATCC53789 and Nostoc sp. GSV 224. ${ }^{[8]}$ Furthermore, specific enzymes involved in its biosynthesis have been heterologously expressed, purified, and characterized including the cryptophycin thioesterase (CrpTE), which is responsible for the macrolactonization of the linear intermediate. ${ }^{[9]}$

Our synthetic approach employed the modified Kenner's safety-catch sulfonamide linker, which was developed in the Ellman laboratory, because of its stability during synthesis. Subsequent $\mathrm{N}$-alkylation of the safety-catch linker results in a labile amide bond that can be displaced by nucleophilic attack with thiols, alcohols, and amines to form thioesters, esters, and amides, respectively. ${ }^{[10]}$ Because of the lability of the activated acylsulfonamide, we envisioned that the nucleophilic serine of CrpTE could directly displace cryptophycin from the solid support after synthesis. A poly(ethylene glycol) $\operatorname{poly}(N, N$ dimethylacrylamide) (PEGA) resin with low levels of substitution was employed so that Crp TE has adequate access to the solid-support-bound substrate. ${ }^{[11]}$

To test the versatility of an enzymatic solid-phase approach we synthesized three cryptophycin thioesterase substrates (3a-c) on safety-catch PEGA resin: seco-desepoxyarenastatin, seco-cryptophycin-29 (seco-desepoxycryptophycin-21), and the seco form of an amide analogue of arenastatin lacking the epoxy or methoxy moieties (Scheme 1). Additionally, these linear substrates were 
<smiles>CC(C)CC(C(=O)NC(=O)CCCS(N)(=O)=O)C(=O)NS(=O)(=O)CCCC(=O)N[O-]</smiles>

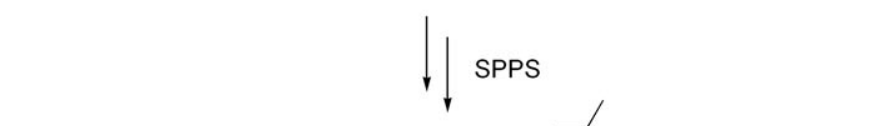<smiles></smiles>

Scheme 1. Synthesis of linear cryptophycin thioesterase substrates $\mathbf{3} a-c$ on solid support. Fmoc $=9$-fluorenylmethyloxycarbonyl, DIPEA $=N, N$-diisopropylethylamine, $\mathrm{PyBOP}=1$-benzotriazolyloxy-tris (pyrrolidino) phosphonium hexafluorophosphate, SPPS $=$ solid-phase peptide synthesis.

chosen to test the tolerance of Crp TE to variations of unit B and to the ester bond between units $\mathrm{C}$ and $\mathrm{D}$ (previous studies have probed the flexibility of CrpTE cyclization of unit C analogues of cryptophycin $\left.{ }^{[9 a]}\right)$.

Fmoc-protected leucic acid, leucine (unit D), $\beta$-alanine (unit C), $O$-methyl-D-tyrosine, 3-chloro- $O$-methyl-D-tyrosine, and D-phenylalanine (unit B) were either commercially available or obtained in a few steps using known procedures. ${ }^{[7]}$ Polyketide unit A was prepared according to the synthesis of
Georg et al. ${ }^{[12]}$ Attachment of unit D (L-leucic acid or leucine) to the commercially available 4-sulfamylbutyryl aminomethyl PEGA resin $\mathbf{1}$ was achieved using PyBOP in dichloromethane; peptide couplings were performed with 2-(1H-benzotriazole-1-yl)-1,1,3,3tetramethyluronium tetrafluoroborate (TBTU); and the ester bond between units $\mathrm{C}$ and $\mathrm{D}$ was formed with mesitylsulfonyl-3-nitro-1,2,4-triazole (MSNT) (Scheme 1).

After alkylation of the acylsulfonamide linker with iodoacetonitrile, the activated resin $(\mathbf{4 a - c})$ was incubated with Crp TE in $\mathrm{pH} 8$ phosphate buffer for $4 \mathrm{~h}^{\left[{ }^{[13]}\right.}$ Extractive workup yielded the cyclized compounds $\mathbf{5 a -}$ c and the corresponding seco-cryptophycins $\mathbf{6 a - c}$ as the only major cleaved products, as determined by HPLC (Scheme 2). The ratio of cyclized and linear products ranged from $4: 1$ to $2: 1$ for the different substrates. Longer incubation times with Crp TE (up to $24 \mathrm{~h}$ ) led to an increased formation of the seco-cryptophycins $\mathbf{6 a - c}$.

Cryptophycins $5 \mathbf{a}-\mathbf{c}$ were obtained after separation by flash chromatography or HPLC in milligram quantities $(5 \mathrm{mg}$ of $\mathbf{5 a}, 6 \mathrm{mg}$ of $\mathbf{5 b}$, and $12 \mathrm{mg}$ of $\mathbf{5 c}$ ). The analytical data of compounds $\mathbf{5} \mathbf{a}$ and $\mathbf{5 b}$ proved to be identical with that reported. ${ }^{[4 c, 12]}$ Significantly, amide analogue $\mathbf{5 c}$ represents a new cryptophycin/arenastatin analogue made accessible through this solid-phase chemoenzymatic approach. ${ }^{[14]}$

In an additional experiment, the activated resin was incubated in $\mathrm{pH} 8$ phosphate buffer without CrpTE. No cyclized products or seco-cryptophycins were observed using the same analytical techniques described above. Therefore, release and cyclization of cryptophycins from solid support are catalyzed by Crp TE. Formation of the seco-cryptophycins 6a-c is apparently mediated by a Crp TE-catalyzed ring-<smiles>[X]C(=O)CCNC(=O)[C@H](Cc1ccc([X])c([X])c1)NC(=O)/C=C/C[C@H](O)[C@H](C)/C=C/c1ccccc1</smiles><smiles>c1ccccc1</smiles><smiles>[X]c1ccc(C[C@H](NC(=O)/C=C/CC[C@H](OC(=O)C(CC(C)C)C([Y])C=Cc2ccccc2)C(=O)NCCC(=O)O)C(C)C)cc1[X]</smiles>

5a: $X^{1}=O, X^{2}=O M e, X^{3}=H$ (desepoxyarenastatin) 5b:, $X^{1}=O, X^{2}=\mathrm{OMe}, X^{3}=\mathrm{Cl}$ (cryptophycin-29) 5c: $X^{1}=\mathrm{NH}, \mathrm{X}^{2}=\mathrm{H}, \mathrm{X}^{3}=\mathrm{H}$<smiles>[X]c1ccc(CC(NC(=O)/C=C/CC(O)C(C)/C=C/c2ccccc2)C(=O)NCCC(=O)[X]C(CC(C)C)C(=O)O)cc1[X]</smiles>

6a: $X^{1}=O, X^{2}=O M e, X^{3}=H$

6b: $X^{1}=O, X^{2}=\mathrm{OMe}, X^{3}=\mathrm{Cl}$

6c: $X^{1}=\mathrm{NH}, \mathrm{X}^{2}=\mathrm{H}, \mathrm{X}^{3}=\mathrm{H}$

Scheme 2. CrpTE-mediated release and macrolactonization of cryptophycins $\mathbf{5 a - c}$ and formation of seco-cryptophycins $\mathbf{6 a - c .}$ 
opening of cryptophycins $\mathbf{5 a - c}$ or by a Crp TE-catalyzed hydrolysis of the solid-phase-bound substrates $\mathbf{4 a - c}$, as previously observed. ${ }^{[9 a]}$

After the first enzymatic cleavage of substrates $4 \mathbf{a}-\mathbf{c}$, a second round of activation and incubation with CrpTE yielded only minor quantities $(<1 \mathrm{mg}$ ) of cryptophycins $\mathbf{5 a}-$ c. This result is in accordance with previous observations that substrates bound to solid support are only partially accessible to enzymes. ${ }^{[2 b]}$ Unlike reported examples for release and macrolactamization of peptides from solid support, treatment of substrates $4 \mathbf{a}-\mathbf{c}$ with a base (e.g. DIPEA or 4-dimethylaminopyridine) did not lead to a macrolactonized product. ${ }^{[15]}$

All Crp TE substrates tested in this study were enzymatically cleaved from the solid support and cyclized. Crp TE displays remarkable tolerance towards selected variations in unit $\mathrm{B}$. The substitution of an ester for an amide between units C and D was also tolerated by Crp TE. Along with the previously reported tolerance of CrpTE for structural variations within $\beta$-alanine (unit $C$ ), these results indicate that Crp TE is a versatile tool for chemoenzymatic synthesis of diverse unit $\mathrm{B}$ and unit $\mathrm{C}$ cryptophycin analogues using this method.

To our knowledge, this is the first report of alkylated acylsulfonamides as suitable enzyme substrates. In addition, this is the first example of macrolactone formation using solid-phase techniques. Combined with the advantages of solid-phase synthesis this enzymatic approach is an efficient and fast method for preparing cryptophycin natural products and related analogues. Owing to the evident versatility of Crp TE, as also shown here, this solid-phase approach can be used to generate rapidly a multitude of new cryptophycin analogues in sufficient yields for bioactivity analysis. In addition, this solid-phase chemoenzymatic approach should be suitable for the synthesis of other macrocyclic and linear natural products.

\section{Experimental Section}

Activation and Crp TE-mediated macrolactonization of solid-phasebound substrates: The substrates $\mathbf{3 a} \mathbf{a}-\mathbf{c}$ on safety-catch PEGA resin (approximately $0.2 \mathrm{mmol}$ ) were washed with several portions of $N$ methylpyrrolidinone (NMP). The swollen resin was treated with NMP (5 mL), DIPEA (11 equiv), and iodoacetonitrile ( 25 equiv), which was filtered through a plug of basic alumina prior to use. The reaction flask was shielded from light and agitated for $24 \mathrm{~h}$ at $35^{\circ} \mathrm{C}$. Resin was washed sequentially with NMP $(5 \times 5 \mathrm{~mL})$, DMF $(5 \times$ $5 \mathrm{~mL})$, water $(5 \times 5 \mathrm{~mL})$ and $\mathrm{pH} 8$ phosphate buffer $(3 \times 5 \mathrm{~mL})$. CrpTE $(3 \mathrm{~mL}, 60 \mu \mathrm{M}$ in $25 \mathrm{~mm}$ phosphate buffer, $\mathrm{pH}$ 8) was added, and the enzyme-resin mixture was left to stand for $4 \mathrm{~h}$ at $23^{\circ} \mathrm{C}$. Next, the resin was washed with water $(2 \times 5 \mathrm{~mL})$ and dichloromethane $(5 \times$ $5 \mathrm{~mL}$ ). After extraction of the aqueous filtrate with dichloromethane, the combined organic extracts and filtrates were dried over $\mathrm{MgSO}_{4}$, filtered, and concentrated under vacuum. Purification by flash chromatography or RP-HPLC yielded the cryptophycins 5 a-c and the seco-cryptophycins $\mathbf{6 a - c}$.

Received: August 10, 2007

Published online: November 2, 2007
Keywords: cryptophycins - macrolactonization .

safety-catch linkers · solid-phase synthesis · thioesterases

[1] a) D. E. Cane, C. T. Walsh, C. Khosla, Science 1998, 282, 63-68; b) M. A. Marahiel, T. Stachelhaus, H. D. Mootz, Chem. Rev. 1997, 97, 2651-2674.

[2] a) R. M. Kohli, C. T. Walsh, M. D. Burkart, Nature 2002, 418, 658-661; b) X. Wu, X. Bu, K. M. Wong, W. Yan, Z. Guo, Org. Lett. 2003, 5, 1749-1752; c) M. Tamaki, K. Honda, S. Kikuchi, R. Ishii, Tetrahedron Lett. 2006, 47, 8475-8478.

[3] a) J. D. Umarye, T. Leßmann, A. B. García, V. Mamane, S. Sommer, H. Waldmann, Chem. Eur. J. 2007, 13, 3305-3319; b) T. Leßmann, H. Waldmann, Chem. Commun. 2006, $3380-$ 3389 ; c) I. Paterson, M. Donghi, K. Gerlach, Angew. Chem. 2000, 112, 3453-3457; Angew. Chem. Int. Ed. 2000, 39, 3315-3319.

[4] a) R. E. Schwartz, C. F. Hirsch, D. F. Sesin, J. E. Flor, M. Chartrain, R. E. Fromtling, G. H. Harris, M. J. Salvatore, J. M. Liesch, K. Yudin, J. Ind. Microbiol. 1990, 5, 113-123; b) T. Golakoti, I. Ohtani, G. M. L. Patterson, R. E. Moore, T. H. Corbett, F. A. Valeriote, L. Demchik, J. Am. Chem. Soc. 1994, 116, 4729-4737; c) T. Golakoti, J. Ogino, C. E. Heltzel, T. L. Husebo, C. M. Jensen, L. K. Larsen, G. M. L. Patterson, R. E. Moore, S. L. Mooberry, T. H. Corbett, F. A. Valeriote, J. Am. Chem. Soc. 1995, 117, 12030-12049.

[5] C. D. Smith, X. Zhang, S. L. Mooberry, G. M. L. Patterson, R. E. Moore, Cancer Res. 1994, 54, 3779-3784.

[6] J. Liang, R. E. Moore, E. D. Moher, J. E. Munroe, R. S. Al-Awar, D. A. Hay, D. L. Varie, T. Y. Zhang, J. A. Aikins, M. J. Martinelli, C. Shih, J. E. Ray, L. L. Gibson, V. Vasudevan, L. Polin, K. White, J. Kushner, C. Simpson, S. Pugh, T. H. Corbett, Invest. New Drugs 2005, 23, 213-224.

[7] Recent reviews: a) S. Eißler, A. Stoncius, M. Nahrwold, N. Sewald, Synthesis 2006, 3747-3789; b) M. Eggen, G. I. Georg, Med. Res. Rev. 2002, 22, 85-101.

[8] N. A. Magarvey, Z. Q. Beck, T. Golakoti, Y. Ding, U. Huber, T. K. Hemscheidt, D. Abelson, R. E. Moore, D. H. Sherman, ACS Chem. Biol. 2006, 1, 766-779.

[9] a) Z. Q. Beck, C. C. Aldrich, N. A. Magarvey, G. I. Georg, D. H. Sherman, Biochemistry 2005, 44, 13457-13466; b) Z. Q. Beck, D. A. Burr, D. H. Sherman, ChemBioChem 2007, 8, 1373-1375.

[10] a) B. J. Backes, A. A. Virgilio, J. A. Ellman, J. Am. Chem. Soc. 1996, 118, 3055-3056; b) B. J. Backes, J. A. Ellman, J. Org. Chem. 1999, 64, 2322-2330.

[11] a) M. Meldal, Tetrahedron Lett. 1992, 33, 3077-3080; b) M. Meldal, F.-I. Auzanneau, O. Hindsgaul, M. M. Palcic, J. Chem. Soc. Chem. Commun. 1994, 1849-1850.

[12] M. Eggen, C. J. Mossman, S. B. Buck, S. K. Nair, L. Bhat, S. M. Ali, E. A. Reiff, T. C. Boge, G. I. Georg, J. Org. Chem. 2000, 65, $7792-7799$.

[13] The use of standard tris(hydroxymethyl)aminomethane (TRIS) buffer leads to significant formation of a cryptophycin-TRIS adduct, as determined by mass spectrometry. Non-nucleophilic buffer systems circumvented this problem.

[14] Similar arenastatin analogues with an amide bond between units $C$ and D have been reported: a) N. Murakami, W. Wang, N. Ohyabu, T. Ito, S. Tamura, S. Aoki, M. Kobayashi, I. Kitagawa, Tetrahedron 2000, 56, 9121-9128; b) N. Kotoku, T. Kato, F. Narumi, E. Ohtani, S. Kamada, S. Aoki, N. Okada, S. Nakagawa, M. Kobayashi, Bioorg. Med. Chem. 2006, 14, 7446-7457.

[15] a) L. Yang, G. Morriello, Tetrahedron Lett. 1999, 40, 8197-8200; b) P. C. de Visser, N. M. A. J. Kriek, P. A. V. van Hooft, A. Van Schepdael, D. V. Filippov, G. A. van der Marel, H. S. Overkleeft, J. H. van Boom, D. Noort, J. Pept. Res. 2003, 61, 298-306. 